\title{
Zoom breakout room for students' collaborative skill enhancement in history learning during Covid-19 outbreak
}

\author{
Ema Agustina ${ }^{1}$, Toto Suharya ${ }^{1}$ \\ ${ }^{1}$ Universitas Pendidikan Indonesia. \\ *Corresponding author, e-mail: emaagustina@upi.edu
}

\begin{abstract}
The new transformation in history learning is needed in online learning, especially when it comes as the effort to improve students' collaborative skills in solving problems, finding solutions, making decisions, and negotiating to achieve particular goals in $21^{\text {st }}$ century learning skills . The virtual learning rooms such as Zoom are used to ensure students' involvement and collaboration in learning and to provide opportunities for students to realize active learning with many features that can be applied. Despite many studies have portrayed virtual learning with Zoom during COVID-19 pandemic, fewer studies seek to the utilization of Zoom Breakout Room in history learning. This study uncovered how teachers enhance students' collaborative skills in history learning through the Zoom Breakout Room. The current study employed the qualitative approach under the case study design. In-depth interviews were directly conducted with one history teacher who experienced in conducting history learning with Zoom Breakout Room to obtain the empirical data. The results showed that Zoom Breakout Room could be used by teachers to improve students' collaborative skill. In the current study, the use of Zoom Breakout Room as one of innovative tools in Virtual Learning Environment (VLE) answered the ineffective learning with large groups in Zoom main room discussion. Breakout Room feature in Zoom itself supported an active learning process since the students are given the more space to communicate in small groups and can seek information, discuss, solve problems, and make collective agreements. The Zoom Breakout Room could be an alternative for teachers in facing the challenges of learning amid COVID-19 outbreak.
\end{abstract}

Keywords: Breakout Room, Collaborative Skill, History Learning

How to Cite: Agustina, E. \& Suharya, T. (2021). Zoom breakout room for students' collaborative skill enhancement in history learning during Covid-19 outbreak. International Journal of Research in Counseling and Education, 5 (1): pp. 33-38, DOI: https://doi.org/10.24036/00430za0002

This is an open access article distributed under the Creative Commons 4.0 Attribution License, which permits unrestricted use, distribution, and reproduction in any medium, provided the original work is properly cited. @2021 by author

\section{Introduction}

In early March 2020, the COVID-19 pandemic began to spread in Indonesia with two people who were confirmed positive (WHO, 2020). The end of 2019 is the beginning of massive changes for the entire world in which almost all countries have been struggling for COVID-19 pandemic which was firstly detected in Wuhan, Central China and was identified then in several provinces in China, Thailand, Japan, United States and South Korea (Huang et al., 2020; Zhou et al., 2020). The emergence of the COVID-19 pandemic has impacted all elements of human life from all countries, including Indonesia. The rapid spreading of COVID-19 pandemic is not only a global health problem because it transmits from one person to another quickly but also it impacts to social, economic, infrastructure and including education (Wong et al., 2020). The impact of the COVID-19 pandemic in Indonesia has also drastically brought massive changes to the Indonesian educational fields.

The current Indonesian president held a press conference regarding the new policies in responding to the COVID-19 Pandemic. He announced that the Large-Scale Social Restriction (PSSB) policy was the policy chosen in response to the health emergency based on the legal basis of Law Number 6 in 2018 concerning health quarantine (Ristyawati, 2020). Moreover, the government has also taken several steps to solve the COVID-19 pandemic cases that massively impact all elements by promoting the social distancing for people. This new rule aims to reduce the COVID-19 infection. People have to maintain their safe distance among each other by limiting physical distance, not making direct contact with other people, avoiding mass gatherings in public spaces that can trigger daily life changes with all around including in educational field (Tesar, 2020); Hamburg, 
2020; Greenhow \& Chapman, 2020). The practical use of social distancing among people aims to stop COVID19 infection by keeping aware to maintain a safe distance for every person that is at least 2 meters, not to make direct contact with other people, and to avoid mass crowds.

To respond, it is appropriate to change the face-to-face learning in schools to online learning as the anticipation to stop the spread of COVID-19 pandemic. This policy is not only realized in Indonesia but also several countries all over the world (Toquero, 2020). So, it is required that the teachers have to teach from home and the students also learn from home for every education level. This policy is stated in the circular letter of the Minister of Education and Culture No. 36962/MHK.A/HK/2020 regarding online learning and working from home in order to prevent the spread of COVID-19 pandemic (Kemendikbud, 2020). Still, the parents and the students also have challenges and obstacles that have to be faced in implementing this policy.

There are many factors that influence the less optimal of online learning. Less focus while learning due to many obstacles from home, less supportive facilities of the students, limited internet quota, parents that have not been ready to accompany students in online learning, even there have been several areas that have limited internet connection, and teachers' readiness to conduct online learning. It needs the synchronization between the policy and the practice. Even so, creating training for developing teachers' competence and collaborating with IT designer and provider to minimalize technical and provider issues are expected to be the solution to overcome those factors (Chertoff et al., 2020; Prata- Linhares et al., 2020).

Regarding the implementation of online learning, many factors can affect online learning such as lack of focus due to many distractions working from home, supporting facilities that are not evenly owned by students and the unready parent to accompany their children, and even the limited internet connection in several region in Indonesia. In another side, online learning encourages teachers to develop skills in using technology and provides innovation to the learning application that cannot be separated from ICT-based learning (Yu et al., 2021). Without innovation, online learning will only become a teacher-centered performance and this will lead to low teacher-student interaction. This will affect student learning motivation and student learning satisfaction (Deng \& Benckendorff, 2017).

There are many platforms for conducting distance learning to ensure student engagement in the learning process from home during COVID-19 pandemic began. The virtual learning rooms, including Zoom, Weber, Google Meet with many features in it are created to ensure students' involvement in learning and provide opportunities for students to realize active learning such as Chat Room, the Breakout Room, Reaction, the Share Screen, Poll, and others (Helmi et al., 2020; Buheji \& Ahmed, 2020). Moreover, Alameri et al., (2020) showed that the use of Zoom during COVID-19 pandemic has positive impact to independent learning and academic achievement. Zoom is also more familiar, universal, and easier to use. All this reasons then make zoom as the best choice to apply in teaching and learning process (Grandinetti, 2021; Ramadani \& Xhaferi, 2020).

Although there were several choices of virtual study rooms, Zoom is the most favorite choice by teachers and students because there are $50 \%$ of teachers and $30 \%$ of students consider Zoom to be more frequently and preferably applied to online learning during the COVID-19 Pandemic era compared to other platforms. (Sakkir et al., 2020). The detailed survey of several platforms popularity from (Populix, 2020) presented that Zoom placed the highest rank as the most popular platform. It indicated that Zoom is the most frequently used of video conferencing during the COVID-19 pandemic era that students used compared to WhatsApp, Skype, Google Duo, Google Meet, Facetime, Microsoft Teams, Discord, Cisco WebEx, dan Slack. Zoom is a web-based video conferencing tool that allows people to meet within online environment such, with or without video. Zoom users can collaborate on projects, record sessions, and share or annotate on-screen annotations with one another in one easy-to-use platform (Chawla, 2020).

Thus, one of the features in the virtual learning platform with Zoom in which there is a Breakout Room feature that can be used in online history learning. Breakout Room is a virtual room in Zoom that is separated from the main room. The use of Breakout Room can be the breakthrough to anticipate the learning obstacle in digital learning (Lee, 2021). The teacher can divide students into several groups and each group can discuss, read messages in chat box and provide opportunities for students to discuss and work independently (Chandler, 2016).

Regarding the practical use of Zoom Breakout Room, it can also be applied in history learning. The new transformation in history learning is needed in online learning, especially when it comes as the effort to improve students' $21^{\text {st }}$ century learning skill. Specifically, as it tries to improve students' collaborative skill. The collaborative skill in history learning include students' competence to collaborate in solving problems, finding solutions, making decisions, and negotiating to achieve particular goals (Hasan, 2019). Therefore, this article tried to answer questions about: How to improve students' collaborative skills through the Zoom Breakout Room in history learning during the COVID-19 outbreak? 


\section{Method}

The current study employed the qualitative approach under the case study design since it is considered as a process of inquiring the answer of research questions addressed by examining what, how, when, and where an event occurred in a particular social context (Berg, 2004; Creswell, 2012). It is also considered to be suitable in the context of the current research as it focuses on revealing the existing phenomena of Zoom Breakout Room utilization as an overt effort in accomplishing comprehension in the literature of students' collaborative skill improvement in history learning. The investigation was conducted under the main issue on how to improve students' collaborative skills through the Zoom Breakout Room in history learning during the COVID19 outbreak.

To obtain the empirical data, in-depth interviews were directly conducted with one history teacher who experienced in conducting history learning with Zoom Breakout Room. To get rich data and to strengthen the ideas on how Zoom Breakout Room can enhance students' collaborative skill, the literature analysis was also attempted as the theoretical reference. This process aimed at synthesizing the interview results of the respondents to look for relevant information with the issues of the current study after conducting interview sessions to the teachers. After getting the data teacher's narrative on how he applied Zoom Breakout Room and its synthesis, the final result of teacher's summary is revealed as the results of this study.

In regards to this study, the particular phenomenon will refer to the one history teacher's narrative on how Zoom Breakout Room can improve students' collaborative skill in history learning in Indonesian context. Further, this study focuses on describing, analyzing, and interpreting the data from selected respondent towards the use of Zoom Breakout Room to improve students' collaborative skill in history learning during COVID-19 pandemic.

\section{Results and Discussion}

The analysis of the interview results would be explained in two categories: (1) Personal and professional identity, (2) History learning with the Breakout Room feature, (3) Collaborative skills for students. The complete and detailed information are presented in the following sections.

\section{Personal and professional identity}

Prior to the participant's personal and professional background, the selected history teacher in this study was three years experienced history teacher who used Zoom Breakout Room in his own classroom. But he committed to keep creating innovation to his own teaching and learning activities. He realized that history teaching and learning activities need new breakthroughs to create more interesting learning because the characteristics of history learning will be very boring if it is not packaged with interesting learning.

To support his commitment, he actively participated in many trainings, communities, and organizations to develop his competence in creating innovative teaching. Beside following Subject Teacher Conference (MGMP), he currently involves as the part of the Indonesian Historian Society (MSI), Teaching Teachers for the Archipelago (GUMUN), Indonesian Teachers Association (IGI), Indonesian History Teachers Association (AGSI), One Week One Innovation (SAMISANOV) and a Youtuber Teacher. Those participation proves that he always tried to make history learning interesting and fun. He was not trapped in conventional learning that still focused on teachers-centered learning. Next, he also tried to infuse ICT-based teaching and learning into his history classroom. It proved that he likely used technology with many applications in it to help him creating contemporary learning for the students. Even so, before COVID-19 pandemic spreading to Indonesia and impacted the teaching and learning environment, he had already implemented blended learning to his classroom as the students' preparedness to face global challenges in $21^{\text {st }}$ century learning.

\section{History learning with Zoom Breakout Room}

The teacher used several topics including the theory of the entry of Hindu-Buddhist to Indonesia. The process of the Hindu-Buddhist arrival to Indonesia is quite controversial. Therefore, with this material the teacher divided the students into five groups for 5 rooms based on the following topic materials.

Table 1. Group Learning Materials

\begin{tabular}{ccl}
\hline Group & Room & \multicolumn{1}{c}{ Material } \\
\hline $\mathbf{1}$ & 1 & The Theory of Brahmins by JC van Leu \\
$\mathbf{2}$ & 2 & The Vaisya theory by NJ. chrome \\
$\mathbf{3}$ & $\mathbf{3}$ & The Knight theory by CC Berg, Mookerji, and JL Moens \\
$\mathbf{4}$ & $\mathbf{4}$ & The Backflow theory by FDK Bosch \\
$\mathbf{5}$ & $\mathbf{5}$ & The Sudra theory by van Faber \\
\hline
\end{tabular}


In detail, Table 1 showed that students have different materials in each group which will be collected in different rooms. In the first teaching and learning activities, it would be started by the teacher in the main room in Zoom. The teacher divided the materials and groups and prepared a room based on the number of groups. After entering the room based on their group, the students would work together to organize materials from various sources. They also would discuss and prepare group members with different roles. Each group member had different responsibilities; as a presenter, a questioner for other groups, responder, and note taker in which practically, the students still helped each other in their group regardles their roles. After preparing students with their groups, each group would be regrouped in the main room to take turns on explaining, then asking questions, defending arguments, and reaching final agreement. This activity was previously conducted by Chandler (2016) who stated that by breaking the zoom room into several rooms and dividing students into several small groups could improve students' confidence since the teachers provide facilities and opportunities for students to carry out activities independently. Additionally, the students' small groups division in several rooms would provide opportunities for students to showing their opinions more freely due to the distance between the teacher and the students so it was possible for the students to learn more optimally during their learning activities in their small groups.

Thus, although in virtual learning, Zoom is very practical and efficient to conduct, but it is not more effective than face-to-face learning before the COVID-19 pandemic era. However, Zoom is still the main choice and alternative in online learning because it can still have face-to-face and verbal communication directly through the screen like real learning in the classroom compared to other similar applications. Additionally, Zoom is also effective if it is associated with the implementation of health protocols. Moreover, zoom will be more maximal if the Breakout Room is used to support an active learning during teaching and learning process in virtual learning environment (VLE). Breakout room in zoom has many supportive features that can support the students to communicate verbally with their small groups and can solve problems that have been shared before grouping them in Breakout room (Cavinato et al., 2021).

Prior to this study, the use of Zoom would be maximal if the Breakout Room feature is used. It also can support an active learning process since the students are exposed more space to communicate in spoken language with small groups and can solve problems that have been given to them at the first process of teaching and learning activities before grouping students and rooms in the Breakout Room. Considerably, Breakout Room in Zoom is also very essential and suitable to use in the current virtual learning environment (VLE) during COVID-19 pandemic. Therefore, the teachers have to improvise and to keep innovating in online learning especially by using the Zoom Breakout Room so that the students can be still involved and not focusing on the teacher anymore during students' learning activities.

\section{Collaborative skills to students}

Collaborative skill is one of students' expected skills in $21^{\text {st }}$ century learning (King, et.al, 2010). Previously explained, Zoom Breakout Room has been conducted during learning history subject matter. Technically, it was conducted by making students' groups, organizing the materials by collecting information, and collaborating those collected information and materials which then presented the overall materials and information. This can significantly improve students skill in the $4 \mathrm{C}$ (critical thinking, creativity, communication, and collaboration) skills (Trilling \& Fadel 2009). In the current study that it was attempted to history learning, students actively did problem-solving, solution findings, decision-making to get collective agreements (Hasan, 2019). In the process of students' collaboration, the students collaborate with group member or with other groups in doing problem-solving by firstly asking to each other to better understanding which then working on the real answer together. Next, different opinion among groups appear and coincidently find the collective answer that has been discussed based on each group opinion. This whole process has been currently considered as building students' collaborative skill (Ironsi, 2021). Naturally, creating project-based tasks in Zoom Breakout Room is also very effective to enhance students' creative skills because they can be actively involved in small groups that push them to share their ideas and working with each other in the same group to finish their project-based tasks and solving problems together. As the result, those activities can enhance students' collaborative skill and social (Cooper, 1990; Heinich, R., 2002).

The opportunity to work collaboratively is also provided by history teachers so that students are able to interpret learning meaningfully from a material, develop critical thinking, and improve their skills. The teachers play significant roles in developing a sense of togetherness and also take parts in encouraging students to understand the material, to focus on discussions, and to help identifying problems so that students are able to solve problems and make mutual agreements (Stover \& Pollock, 2014). Technically, in Zoom Breakout Room, the students are divided into several small groups which they supposed to work together flexibly in discussing the materials. This will stimulate and enhance students/ collaborative skill. Zoom Breakout Room also plays an important role for students to develop their understanding of the concepts that have been shared in the main room (Tonsmann, 2014). Not only enhancing students' collaborative skill, Zoom Breakout Room is also effective to support the cooperative learning and it indirectly can also enhance students' collaborative skill. This is in 
line with Hendarwati, et al (2021) who stated that improving collaborative skill in problem-solving is relatively difficult to do and to improve during virtual learning in COVID-19 pandemic. As the result, Zoom Breakout Room is one of effective solution to improve effective learning in enhancing students' collaborative skill in problem-solving.

\section{Conclusion}

Zoom was still considered to be not effective enough to be used in learning. It is worth mentioning that the breakout room feature in Zoom could be used as an alternative to maximize leaning especially history learning. The students can participate during their learning process and the teachers can be the facilitator. The roles of teacher, the facilitator, is the main focus of $21^{\text {st }}$ century learning that the roles of teachers have shifted. Now, teachers do not take the central role in the classroom but it changes their absolute roles previously. By maximizing the use of Zoom Breakout Room, the students can have online social interactions and it is possible to build close relationships among students. Although the whole process of teaching and learning is conducted virtually, the students can have discussions with each small group which can make students learn collaboratively. The efforts to improve students' collaborative skills are carried out by utilizing the Breakout Room feature. Teachers can provide opportunities for students to work together with small groups in finding information, organizing materials, sharing roles, discussing, asking questions, solving problems and making collective agreements. Again, by utilizing the Zoom Breakout Room, it considerably supported students' collaborative skill enhancement. In this study, the history teachers also can provide more opportunities for students to work together closely with small groups in collecting information, organizing materials, sharing roles, discussing materials, asking questions, and making collective agreements.

\section{References}

Alameri, J., et.al. (2020). Students' perceptions of e-learning platforms (moodle, microsoft teams and zoom platforms) in the university of Jordan Education and its relation to self-study .... Advanced Research \& Studies Journal, 11(5), 21-33. https://www.researchgate.net/profile/RajaMasadeh/publication/344225336_Students'_Perceptions_of_E-

learning_platforms_Moodle_Microsoft_Teams_and_Zoom_platforms_in_The_University_of_Jordan_Edu cation_and_its_Relation_to_self-study_and_Academic_Achievement_D

Berg, B. (2004). In qualitative research methods for the social sciences (pp. 195-208). Pearson.

Cavinato, A. G., Hunter, R. A., Ott, L. S., \& Robinson, J. K. (2021). Promoting student interaction, engagement, and success in an online environment. Analytical and Bioanalytical Chemistry, 413(6), 1513-1520. https://doi.org/10.1007/s00216-021-03178-X

Chandler, K. (2016). Using breakout rooms in synchronous online tutorials. Journal of Perspectives in Applied Academic Practice, 4(3), 16-23. https://doi.org/10.14297/jpaap.v4i3.216

Chawla, A. (2020). Coronavirus (COVID-19) - 'zoom' application boon or bane. Papers.Ssrn.Com.

Chertoff, J. D., Zarzour, J. G., Morgan, D. E., Lewis, P. J., Canon, C. L., \& Harvey, J. A. (2020). The early influence and effects of the coronavirus disease 2019 (COVID-19) pandemic on resident education and adaptations. Journal of the American College of Radiology, 1710), 1322-1328. https://doi.org/10.1016/j.jacr.2020.07.022

Cooper, J. M. (1990). Classroom teaching skill. Lexington, Massachusetts Toronto: DC.Heath and Company.

Creswell, J. W. (2012). Research design. SAGE Publications Ltd.

Deng, R., \& Benckendorff, P. (2017). A contemporary review of research methods adopted to understand students' and instructors' use of massive open online courses (MOOCs). International Journal of Information and Education Technology, 78), 601-607. https://doi.org/10.18178/ijiet.2017.7.8.939

Grandinetti, J. (2021). Pandemic Pedagogy, zoom, and the surveillant classroom: the challenges of living our advocacies in a pandemic. Communication, Culture and Critique, 14(2), 347-350. https://doi.org/10.1093/ccc/tcab021

Greenhow, C., \& Chapman, A. (2020). Social distancing meet social media: digital tools for connecting students, teachers, and citizens in an emergency. Information and Learning Science, 121(5-6), 331-342. https://doi.org/10.1108/ILS-04-2020-0134

Hamburg, I. (2020). Creating innovative structures in workplace and vocational digital learning to ensure social distancing. ICDS 2020: The Fourteenth International Conference on Digital Society, c, 124-127. https://www.iat.eu/aktuell/veroeff/2020/hamburg06.pdf

Hasan, H. S. (2019). Pendidikan sejarah untuk kehidupan abad ke 21. HISTORIA: Jurnal Pendidik Dan Peneliti Sejarah, II(2), 61-72.

Heinich, R., et. al. (2002). Instructional media and technologies for learning. New Jersey: Prentice Hall, Englewood Cliffs.

Helmi, S. A., Mohd-yusof, K., \& Zakaria, Z. Y. (2020). Guideline to an effective implementation of student- 
centered learning in engineering education: Informal Cooperative Learning (ICL ). ASEAN Journal of Engineering Education, 4(2), 55-61.

Hendarwati, E., Nurlaela, L., Bachri, B. S., \& Sa'ida, N. (2021). Collaborative Problem based learning integrated with online learning. International Journal of Emerging Technologies in Learning, 16(13), 29-39. https://doi.org/10.3991/ijet.v16i13.24159

Huang, C.,et.al. (2020). Clinical features of patients infected with 2019 novel coronavirus in Wuhan, China. The Lancet, 395(10223), 497-506. https://doi.org/10.1016/S0140-6736(20)30183-5

Ironsi, C. S. (2021). Strategies for student participation with remote online learning: Instructor expectations. The International Journal of Social Sciences World (TIJOSSW), 3(1), 24-36. https://www.growingscholar.org/journal/index.php/TIJOSSW/article/view/53

King, F.J., Goodson, L., M.S., dan Rohani, F. (2010). Higher order thinking skills. Assessment dan Evaluation Educational Service Program.

Lee, A. R. (2021). Breaking through digital barriers: Exploring EFL students' views of zoom breakout room experiences. Korean Journal of English Language and Linguistics, 21(June), 510-524. https://doi.org/10.15738/kjell.21..202106.510

Populix. (2020). Top 10 online video conferencing platforms. https://Www.Info.Populix.Co/Post/VideoConference.

Prata- Linhares, M. M., Cardoso, T. da S. G., Lopes-Jr, D. S., \& Zukowsky-Tavares, C. (2020). Social distancing effects on the teaching systems and teacher education programmes in Brazil: reinventing without distorting teaching. Journal of Education for Teaching, 46(4), 554-564. https://doi.org/10.1080/02607476.2020.1800406

Ramadani, A., \& Xhaferi, B. (2020). Teachers' experiences with online teaching using the zoom platform with efl teachers in high schools in kumanova. SEEU Review, 15(1), 142-155. https://doi.org/10.2478/seeur2020-0009

Ristyawati, A. (2020). Efektifitas kebijakan pembatasan sosial berskala besar dalam masa pandemi corona virus 2019 oleh pemerintah sesuai amanat UUD NRI Tahun 1945. Administrative Law and Governance Journal, 3(2), 240-249. https://doi.org/10.14710/alj.v3i2.240-249

Sakkir, G., Dollah, S., \& Ahmad, J. (2020). Favorite e-learning media in pandemic covid-19 era (Universitas Muhammadiyah Sidenreng Rappang). Jurnal Studi Guru Dan Pembelajaran, 3(3), 480-485. https://www.e-journal.my.id/jsgp/article/view/435

Stover, S., \& Pollock, S. (2014). Building a community of inquiry and analytical skills in an online history course. International Journal of Teaching and Learning in Higher Education, 26(3), 393-403. http://www.isetl.org/ijtlhe/

Tesar, M. (2020). Towards a Post-covid-19 ‘new normality?': Physical and social distancing, the move to online and higher education. Policy Futures in Education, 18(5), 556-559. https://doi.org/10.1177/1478210320935671

Tonsmann, G. (2014). A study of the effectiveness of blackboard collaborate for conducting synchronous courses at multiple locations. InSight: A Journal of Scholarly Teaching, 9, 54-63. https://doi.org/10.46504/09201404to

Toquero, C. M. (2020). Challenges and opportunities for higher education amid the COVID-19 Pandemic: The Philippine context. Pedagogical Research, 5(4), 1-5. https://doi.org/10.29333/pr/7947

Trilling, B. \& Fadel, C. (2009). 21st Century skills learning for life in our times . San Francisco: Jossey-Bass.

WHO. (2020). Coronavirus Disease 2019 (COVID-19) World Health Situation Report - 1. In WHO Indonesia Situation Report (Vol. 2019, Issue March).

Wong, G. L. H., et.al. (2020). Management of patients with liver derangement during the COVID-19 pandemic: an Asia-Pacific position statement. The Lancet Gastroenterology and Hepatology, 5(8), 776-787. https://doi.org/10.1016/S2468-1253(20)30190-4

Yu, H., Liu, P., Huang, X., \& Cao, Y. (2021). Teacher Online informal learning as a means to innovative teaching during home quarantine in the COVID-19 pandemic. Frontiers in Psychology, 12(June), 1-12. https://doi.org/10.3389/fpsyg.2021.596582

Zhou, S., Wang, Y., Zhu, T., \& Xia, L. (2020). CT features of coronavirus disease 2019 (COVID-19) pneumonia in 62 patients in Wuhan, China. American Journal of Roentgenology, 214(6), 1287-1294. https://doi.org/10.2214/AJR.20.22975 